\title{
ASPECTS OF FREE RADICAL OXIDATION IN THE LARGE BOWEL IN ULCERATIVE COLITIS AND CROHN'S DISEASE
}

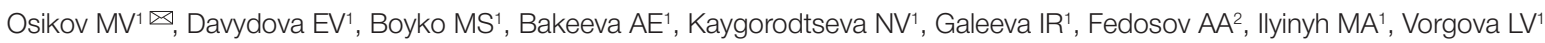

South Ural State Medical University, Chelyabinsk, Russia

2 Pirogov Russian National Research Medical University, Moscow, Russia

Research into the accumulation patterns of protein oxidative modification (POM) products and lipids in Crohn's disease (CD) and ulcerative colitis (UC) could have important implications for understanding the pathogenesis and improving the diagnosis and therapy for these diseases. The aim of this study was to investigate the aspects of free radical oxidation (FRO) in the large bowel and their possible correlations with clinical symptoms of UC and CD. In the Wistar rat model used in the experiment, CD was induced with 2,4,6-trinitrobenzenesulfonic acid, and UC was induced with oxazolone. Clinical status was assessed using the Disease activity index (DAI). Lipid peroxidation (LPO) products were measured in the heptane and isopropanol phases of the intestinal mucosa extract. POM products were measured following spontaneous and stimulated oxidation. The $\mathrm{DAl}\left(\mathrm{Me}\left(\mathrm{Q}_{25}-\mathrm{Q}_{75}\right)\right)$ was increased in both $\mathrm{CD}$ and $\mathrm{UC}$ on days 3 and 7 of the experiment: for $C D$, it was equally increased on days 3 and 7 (7 (3-7)) and was 11 (11-11) and 11 (9-11) for $U C$ on days 3 and 7 , respectively. The amount of primary, secondary and end LPO products in the heptane and isopropanol phases, as well as the total amount of POM products, was increased in the homogenized mucosa of the large bowel. In the CD group, the relative content of secondary basic POM products was increased on day 7 of the experiment. The following patterns of FRO were revealed: accumulation of LPO products in the UC group and accumulation of POM products in the CD group; UC is characterized by the accumulation of mostly LPO products in the heptane phase and secondary LPO products in the isopropanol phase; $C D$ is characterized by the accumulation of secondary basic POM products. DAl scores were correlated with the amount of LPO products in the isopropanol phase and the amount of POM products in the spontaneous oxidation mode. The highest number of strong correlations was observed in the UC group. Our findings suggest a very serious contribution of FRO changes to the pathogenesis of $\mathrm{UC}$ and $\mathrm{CD}$, meaning that $\mathrm{LPO}$ and POM products could be regarded as diagnostic markers and indicators of treatment efficacy.

Keywords: oxidative stress, lipid peroxidation, protein oxidative modification, large bowel, ulcerative colitis, Crohn's disease

Author contribution: Osikov MV conceived and designed the study, analyzed the experimental data and contributed to writing the manuscript; Davydova EV conceived and designed the study, analyzed the experimental data and contributed to writing the manuscript; Boyko MS, Bakeeva AE, Kaygorodtseva NV, Galeeva IR collected the samples, performed statistical analysis and data interpretation; Fedosov AA analyzed the experimental data and contributed to writing the manuscript; llyinyh MA, Vorgova LV analyzed the experimental data and contributed to writing the manuscript. All authors read and approved the final version of the manuscript for publication.

Compliance with ethical standards: the study was approved by the Ethics Committee of South Ural State Medical University, Chelyabinsk (Protocol No. 11 dated December 27, 2017; Protocol № 1 dated January 22, 2020). The experiment was carried out under standard vivarium conditions in strict compliance with the guidelines on the care and use of animals for scientific purposes provided in the European Convention (ETS № 123 dated March 18, 1986, Strasbourg), European Commission Recommendation 2007/526/EC dated June 18, 2007, and Directive 2010/63/EU of the European Parliament and European Council dated September 22, 2010.

$\triangle$ Correspondence should be addressed: Mikhail V. Osikov

Vorovskogo, 64, Chelyabinsk, 454092; prof.osikov@yandex.ru

Received: 18.04.2020 Accepted: 04.05.2020 Published online: 08.05.2020

DOI: $10.24075 /$ brsmu.2020.027

\section{ОСОБЕННОСТИ СВОБОДНОРАДИКАЛЬНОГО ОКИСЛЕНИЯ В ТОЛСТОМ КИШЕЧНИКЕ ПРИ ЯЗВЕННОМ КОЛИТЕ И БОЛЕЗНИ КРОНА}

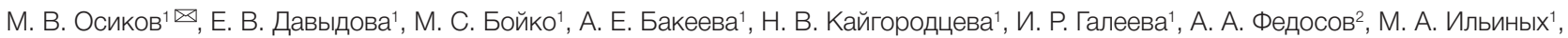
Л. В. Воргова ${ }^{1}$

Южно-Уральский государственный медицинский университет, Челябинск, Россия

2 Российский национальный исследовательский медицинский университет имени Н. И. Пирогова, Москва, Россия

Изучение особенностей накопления продуктов окислительной модисикации белков (ОМБ) и липидов в кишечнике при болезни Крона (БК) и язвенном колите (ЯК) может иметь значение в патогенезе, диагностике и терапии этих заболеваний. Целью работы было изучить особенности свободнорадикального окисления (СРО) в толстом кишечнике, связь с клиническими симптомами при БК и ЯК. Для моделирования БК крысам Wіstar вводили тринитробензосульфат, для ЯК — оксазолон. Клинический статус оценивали по Disease activity index (DAl). В толстом кишечнике определяли продукты пероксидного окисления липидов (ПОЛ) в гептановой и изопропанольной фазах, продукты ОМБ в спонтанном и металл-зависимом режимах. При БК и ЯК на 3-и и 7-е сутки увеличивается DAI (Mе $\left(Q_{25}-Q_{75}\right)$ : 7 (3-7) при БК на 3-и и 7-е сутки одинаково; 11 (11-11) и 11 (9-11) при ЯК на 3-и и 7-е сутки соответственно), в толстом кишечнике повышается количество первичных, вторичных и конечных продуктов ПОЛ в гептановой и изопропанольной фазах, суммарное количество продуктов ОМБ, при БК на 7-е сутки увеличивается доля вторичных продуктов ОМБ основного характера. Особенности СРО: при ЯК - накопление продуктов ПОЛ, при БК - продуктов ОМБ; при ЯК прежде всего накапливаются конечные продукты ПОЛ в гептановой фазе и вторичные продукты в изопропанольной; при БК - вторичные продукты ОМБ основного характера. При БК и ЯК установлена ассоциация DАІ с содержанием продуктов ПОЛ преимущественно в изопропанольной фазе, продуктов ОМБ в спонтанном режиме; наибольшее количество сильных связей зафиксировано при ЯК. По результатам исследования, роль изменений СРО в патогенезе БК и ЯК гораздо больше, что является предпосылкой для обозначения продуктов ПОЛ и ОМБ как диагностических маркеров, показателей эффективности терапии.

Ключевые слова: окислительный стресс, пероксидное окисление липидов, окислительная модификация белков, кишечник, язвенный колит, болезнь Крона Вклад авторов: М. В. Осиков - концепция и дизайн исследования, анализ полученных данных, написание и редактирование рукописи; Е. В. Давыдова концепция и дизайн исследования, анализ полученных данных, написание текста; М. С. Бойко, А. Е. Бакеева, Н. В. Кайгородцева, И. Р. Галеева сбор экспериментального материала, статистическая обработка и анализ полученных данных; А. А. Федосов - анализ результатов, написание и редактирование рукописи; М. А. Ильиных, Л. В. Воргова - анализ результатов, редактирование рукописи. Все авторы прочли и одобрили финальную версию статьи.

Соблюдение этических стандартов: исследование одобрено этическим комитетом ЮУГМУ г. Челябинск (протокол № 11 от 27 декабря 2017 г., протокол № 1 от 22 января 2020 г.). Эксперимент выполнен в стандартных условиях вивария ЮУГМУ при строгом соблюдении требований по уходу и содержанию животных, выводу их из эксперимента и утилизации в соответствии с Европейской конвенцией (ЕТS № 123 от 18.03 .1986 г.

$\square$ Для корреспонденции: Михаил Владимирович Осиков

ул. Воровского, д. 64, г. Челябинск, 454092; prof.osikov@yandex.ru

Статья получена: 18.04.2020 Статья принята к печати: 04.05.2020 Опубликована онлайн: 08.05.2020 DOI: $10.24075 /$ vrgmu.2020.027 
The incidence of gastrointestinal diseases doubles every decade, both in Russia and globally, posing a serious concern to public health and society [1]. Although there is great variability in the epidemiological data across studies, an increase in the incidence of ulcerative colitis (UC) and Crohn's disease (CD), especially in young, socially active and employable individuals, is being reported by many authors [2, 3]. Worldwide, there are 3 to 62 and 50 to 70 incident cases of $U C$ and CD, respectively, per 100,000 population a year [4]. Currently, as many as 1.6 million people are suffering from UC and CD in the USA $[5,6]$. $\mathrm{UC}$ and $\mathrm{CD}$ are also associated with a variety of intestinal and extraintestinal complications that add to hospitalization, surgery and outpatient care costs.

The pathogenesis of $U C$ and CD is not fully clear: there are a multitude of etiological factors that can activate cellmediated and humoral components of the immune system by eliciting Th1 and Th2 immune responses and cause an imbalance between Th17 and $T_{\text {reg }}$ cells [7]. Just like cytokines, enzymes, immunoglobulins, and some other factors, reactive oxygen and nitrogen species (ROS, RNS) produced by activated neutrophils, monocytes/macrophages, endothelial and epithelial cells are involved in triggering and maintaining inflammation in the intestinal wall when there is deficit of antioxidant defense factors [8-10]. ROS and RNS, as well as products of their interaction with proteins and lipids, can act as markers of intestinal tissue damage, indicating the severity of the disease and the efficacy of treatment; they are also potential targets for novel personalized therapeutic and preventive approaches to the regulation of the local redox state in the large bowel affected by CD and UC [11-13]. Therefore, it would be interesting to study the aspects of free radical oxidation (FRO) and the relationship between the redox state of the intestinal lesion and the severity of clinical manifestations in UC and CD.

In our in vivo experiment described below, we aimed to investigate the aspects of $\mathrm{FRO}$ in the large intestine and the relationship between $\mathrm{FRO}$ and the clinical manifestations of UC and CD.

\section{METHODS}

The experiment was conducted in 35 male Wistar rats weighing 200-230 g. The animals were randomized into 3 groups: group 1 served as the intact control $(n=7)$; group 2 included animals with CD $(n=14)$; group 3 consisted of rats with $\cup C(n=14)$. The following procedure was applied to induce $C D$ in the animals: $30 \mathrm{mg}$ of 2,4,6-trinitrobenzenesulfonic acid (TNBS; SigmaAldrich; USA) was dissolved in $150 \mathrm{ml}$ of $50 \%$ ethanol; 0.2 $0.3 \mathrm{ml}$ of the solution (depending on the animal's weight) was injected through a $2 \mathrm{~mm}$ polyurethane catheter (Sintez; Russia) inserted rectally to a depth of $8 \mathrm{~cm}$ [14]. A two-step oxazolonebased scheme was used to induce UC. In the first step, the animals were sensitized with $150 \mu \mathrm{l}$ of $3 \%$ alcohol solution of oxazolone (Sigma-Aldrich; USA) applied onto the skin in the interscapular region; in the second step, $150 \mu$ of $3 \%$ alcohol solution of oxazolone was rectally injected to a depth of $7-8 \mathrm{~cm}$ [15]. Before the procedure, the animals were anesthetized with 20 mg/kg Zoletil 100 (tiletamine hydrochloride; Virbac Sante Animale; France). CD and UC were evaluated based on the clinical symptoms and the morphology of the intestinal lesion on days 3 and 7 . Symptoms were evaluated on a daily basis using a modified disease activity index (DAl) adapted to rats $[16,17]$. Parameters assessed by DAl and the corresponding scores are provided in Table 1. Liquid stools were defined as unformed fecal matter of mash-like or watery consistency. Diarrhea was defined as passage of unformed stools more than 3 times a day. Rectal bleeding was defined as the presence of fresh blood on the animal's fur around the anus and in the feces. The presence of occult blood in the feces was evaluated using the benzidine test.

To prepare a sample of $10 \%$ intestinal mucosa homogenate, the proximal colon was removed and placed in a cooled $0.1 \mathrm{M}$ phosphate buffer solution (pH 7.4); then $100 \mathrm{mg}$ of the tissue was homogenized in a mechanical glass tissue grinder $(1: 10)$ for $3 \mathrm{~min}$ at $\leq 4^{\circ} \mathrm{C}$. These conditions were applied to obtain 1 $\mathrm{ml}$ of homogenized intestinal mucosa. Lipid peroxidation (LPO) products contained in the homogenate were extracted in a mixture of heptane and isopropanol and measured using an SF-56 spectrophotometer (LOMO-Spectr; Saint-Petersburg) following the technique proposed by Volchegorsky et al. [18, 19]. Absorbance of heptane and isopropanol extracts was measured at $220 \mathrm{~nm}$ (isolated double bonds), $232 \mathrm{~nm}$ (diene conjugates, DC), $278 \mathrm{~nm}$ (ketodienes, KD, and conjugated trienes, CT), and $400 \mathrm{~nm}$ (Schiff bases, SB). The relative content of LPO products was expressed in the units of oxidation indices (UOI): E232/E220 (DC), E278/E220 (KD and CT) and E400/ E220 (SB). To quantify products of oxidative protein modification (POM) in the homogenized tissue, carbonyl protein derivatives were allowed to react with 2,4-dinitrophenylhydrazine (two

Table 1. Parameters assessed by DAl

\begin{tabular}{|c|c|c|}
\hline Parameter & Score & Description \\
\hline \multirow{5}{*}{ Body weight loss } & 0 & No weight loss \\
\hline & 1 & $1-5 \%$ \\
\hline & 2 & $6-10 \%$ \\
\hline & 3 & $11-20 \%$ \\
\hline & 4 & Over $20 \%$ \\
\hline \multirow{3}{*}{ Stool consistency } & 0 & Normal stool consistency \\
\hline & 2 & Unformed stool \\
\hline & 4 & Diarrhea \\
\hline \multirow{4}{*}{ Rectal bleeding } & 0 & No blood in feces \\
\hline & 1 & Positive benzidine test \\
\hline & 2 & Positive benzidine test and visible blood in feces \\
\hline & 4 & Rectal bleeding, blood around anus \\
\hline
\end{tabular}


types of oxidation were tested: spontaneous and catalyzed by the Fenton reagent) and the resulting aldehyde/ketone DNPH derivatives were spectrophotometrically measured in the UV and visible regions of the spectrum [20, 21]. Measurement results were expressed in absorbance units per $1 \mathrm{mg}$ of the protein (au/mg) and as percentage (\%). Adaptive reserve potential (ARP, \%) was calculated as a ratio of spontaneous oxidation products to induced oxidation products. The results were processed in IBM SPSS Statistics 19 (SPSS: An IBM Company; USA). The obtained values are presented below as a median $(\mathrm{Me})$ and an interquartile range $\left[\mathrm{Q}_{1}-\mathrm{Q}_{3}\right]$. Significance of differences between the groups was assessed using the Kruskal-Wallis, Mann-Whitney and Wald-Wolfowitz tests. Correlations between the studied parameters were evaluated using Spearmen's rank correlation test. The differences were considered significant at $p<0.05$.

\section{RESULTS}

On day 3 of the experiment, the animals with experimentally induced $C D$ started exhibiting the following symptoms: frequent defecation, changes in stool consistency and blood in feces. On day 7 , the symptoms deteriorated and were now accompanied by weight loss; those changes were reflected in the heightened DAI scores, as shown in Table 2. In addition, the animals became less active. On day 7 , the DAl scores were significantly higher than on day $3(p<0.05)$. Changes were also observed in the amount of LPO products in the lipid extract from the homogenized intestinal mucosa (Table 3). On day 3, there was an increase in the amount of primary and secondary LPO products in the heptane phase and primary, secondary and end LPO products in the isopropanol phase. On day 7 , there was an increase in the amount of primary, secondary and end LPO products in both heptane and isopropanol phases. Thus, the primary and end products of lipid peroxidation were building up between days 3 and 7 in the animals with $C D$, as seen from the isopropanol extracts $(p<0.01)$. In the next step, we quantified products of spontaneous and stimulated oxidative protein modification in the homogenates of large bowel tissue (Table 3).

We found that the total amount of carbonyl protein derivatives was elevated on days 3 and 7 of observation. Carbonyl protein derivatives are irreversible products of oxidative stress. They are formed when a number of amino acid residues undergo oxidation and also when lipid peroxidation products interact with reducing sugars. The total amount of POM products was higher on day 7 than on day $3(p<0.01)$. When analyzing their relative content in the animals with $\mathrm{CD}$, we discovered that on day 7 the share of primary products (aldehydes) shrank while the proportion of secondary products (ketones) increased. As neutral carbonyl derivatives absorb in the UV spectrum, whereas basic carbonyl derivatives absorb in the visible light region, the analysis of cumulative absorption in the UV and visible regions of the spectrum can shed light on the nature of POM products and their accumulation dynamics. On day 3 , the proportion of neutral and basic POM products did not differ between the animals with CD and the intact group. On day 7 , there was a shift towards accumulation of basic POM products, signaled by a decline in their total relative content in the UV spectrum and an increase in their total relative content in the visible region.

The adaptive reserve potential was estimated by calculating the total amount of POM products generated by spontaneous and stimulated oxidation. Briefly, protein oxidation in the intestinal mucosa homogenate was catalyzed by adding $\mathrm{Fe}^{2+}$ and $\mathrm{H}_{2} \mathrm{O}_{2}$ to the reaction mix; the reaction yielded a highly reactive $\mathrm{OH}^{\cdot}$ radical. We found that the total amount of $\mathrm{POM}$ products yielded by stimulated oxidation was elevated on days 3 and 7 of the experiment in the animals with experimentally induced CD. On day 3, the proportion of primary and secondary POM products (both basic and neutral) did not differ from that in the intact animals; on day 7 , the proportion of neutral aldehydes decreased and the proportion of basic ketones went up. So, changes in POM characteristics were similar for both spontaneous and stimulated oxidation modes. The total adaptive reserve potential was significantly increased on day 3 of the experiment and did not differ from that in the intact group on day 7 . This phenomenon can be explained by the enhancement of the adaptive reserve potential of aldehyde/ ketone DNPH derivatives registered in the UV and visible light regions; however, ketone DNPH derivatives registered in the visible light region were the biggest contributor.

On day 3 , the following symptoms were observed in the animals with UC: body weight loss, frequent defecation, loose stools, visible blood in feces, positive benzidine tests. On day 7 , the symptoms deteriorated, as reflected in the heightened DAI scores (Table 2). The DAl scores were significantly higher on day 7 than on day $3(p<0.05)$. On day 3 , primary, secondary and end products of lipid peroxidation were significantly elevated in the heptane and isopropanol phases in this group of animals (Table 3). Similarly, primary, secondary and end products of lipid peroxidation were significantly elevated in the heptane and isopropanol phases on day 7 . Thus, primary and secondary LPO products were declining in the isopropanol phase between the days 3 and 7 in the animals with experimentally induced UC $(p<0.01)$.

In this group of animals, the total content of POM products yielded by stimulated oxidation was significantly increased on days 3 and 7 of the experiment (Table 3). On days 3 and 7 , the share of aldehyde DNPH derivatives shrank, whereas the share of ketone DNPH derivatives went up. On day 7 , the relative amount of basic carbonyl derivatives was increased, in contrast to the reduced share of neutral carbonyl derivatives (this was inferred from an increase in the total relative content of POM products in the visible light region and their low total relative content in the UV region). The total amount of POM products yielded by stimulated oxidation was elevated on days 3 and 7 . The share of aldehyde DNPH derivatives decreased whereas the share of ketone DNPH derivatives increased on days 3 and 7 . The total relative content of POM products registered in the visible light spectrum was significantly elevated on day 3 , suggesting a shift towards formation of basic aldehyde and ketone DNPH derivatives. The total adaptive reserve potential was significantly reduced on days 3 and 7 .

Table 2. Disease activity index in rats with $\cup C$ and $C D\left(M e\left(Q_{25}-Q_{75}\right)\right)$

\begin{tabular}{|c|c|c|c|c|c|}
\hline \multirow[b]{2}{*}{ Parameter } & \multirow{2}{*}{$\begin{array}{l}\text { Group } 1 \\
\text { Intact animals } \\
(n=7)\end{array}$} & \multicolumn{2}{|c|}{ Day 3} & \multicolumn{2}{|c|}{ Day 7} \\
\hline & & $\begin{array}{c}\text { Group 2 } \\
\mathrm{CD}(n=7)\end{array}$ & $\begin{array}{c}\text { Group } 3 \\
\text { UC }(n=7)\end{array}$ & $\begin{array}{c}\text { Group 2 } \\
\operatorname{CD}(n=7)\end{array}$ & $\begin{array}{c}\text { Group } 3 \\
\text { UC }(n=7)\end{array}$ \\
\hline DAl, a.u. & 0 & $7(3.00-7.00)^{*}$ & $7(3.00-7.00)^{*}$ & $11(11.00-11.00)^{*}$ & $11(9.00-11.00)^{\star}$ \\
\hline
\end{tabular}


The correlation analysis established correlations between DAl scores (the integral indicator of the clinical status) and the amounts of LPO/POM products in the homogenized intestinal mucosa of the large bowel (Table 4). On day 3, there were moderate correlations in the CD group between DAI scores and the amount of secondary LPO products in the heptane and isopropanol phases, as well as the total amount of POM products yielded by spontaneous oxidation. In the UC group, DAl scores were strongly correlated with the amount of secondary LPO products in the heptane phase, primary and secondary LPO products in the isopropanol phase, and the total amount of POM products yielded by spontaneous and stimulated oxidation. On day 7, DAl scores correlated with the amount of primary LPO products in the heptane phase, primary, secondary and end LPO products in the isopropanol phase, and the total amount of POM products yielded by spontaneous and stimulated oxidation; for UC, DAl scores were strongly correlated with the amount of primary and end LPO products in the heptane phase, primary, secondary and end LPO products in the isopropanol phase, and the total amount of POM products yielded by spontaneous and stimulated oxidation. The largest number of strong correlations was observed for UC: 10 out of 12 correlations were strong; by contrast, only 1 of 9 correlations established in the CD group was strong.

\section{DISCUSSION}

In our experiment, clinical manifestations of experimentally induced CD and UC were consistent with the actual symptoms and signs of these diseases, suggesting that the proposed TNBS and oxazolone-based animal models can be used to study the pathogenesis of homeostatic changes characteristic

Table 3. Markers of free radical oxidation in the homogenate of large intestinal mucosa of rats with $C D$ and $U C\left(M e\left(Q_{25}-Q_{75}\right)\right)$

\begin{tabular}{|c|c|c|c|c|c|}
\hline \multirow{3}{*}{ Parameter } & \multirow{2}{*}{$\begin{array}{c}\text { Group } 1 \\
\text { Intact animals }\end{array}$} & \multicolumn{2}{|c|}{ Day 3} & \multicolumn{2}{|c|}{ Day 7} \\
\hline & & Group 2 & Group 3 & Group 2 & Group 3 \\
\hline & $(n=7)$ & $\mathrm{CD}(n=7)$ & UC $(n=7)$ & $\mathrm{CD}(n=7)$ & UC $(n=7)$ \\
\hline \multirow{2}{*}{ DC (h), UOI } & 0.63 & 0.79 & 0.79 & 0.75 & 0.76 \\
\hline & $(0.55-0.65)$ & $(0.79-0.81)^{\star}$ & $(0.75-0.81)^{\star}$ & $(0.74-0.81)^{\star}$ & $(0.75-0.77)^{\star}$ \\
\hline \multirow{2}{*}{$\mathrm{KD}$ and $\mathrm{CT}(\mathrm{h}), \mathrm{UOI}$} & 0.06 & 0.09 & 0.08 & 0.07 & 0.09 \\
\hline & $(0.05-0.06)$ & $(0.06-0.09)^{\star}$ & $(0.07-0.08)^{*}$ & $(0.06-0.09)$ & $(0.09-0.11)^{\star} \#$ \\
\hline \multirow{2}{*}{ SB (h), UOI } & 0.01 & 0.01 & 0.03 & 0.03 & 0.05 \\
\hline & $(0.01-0.02)$ & $(0.01-0.01)$ & $(0.02-0.04)^{*} \#$ & $(0.03-0.04)^{\star}$ & $(0.04-0.06)^{\star} \#$ \\
\hline \multirow{2}{*}{ DC (i), UOI } & 0.34 & 0.38 & 0.38 & 0.43 & 0.43 \\
\hline & $(0.32-0.36)$ & $(0.38-0.45)^{\star}$ & $(0.33-0.43)^{\star}$ & $(0.41-0.45)^{\star}$ & $(0.43-0.45)^{\star}$ \\
\hline \multirow{2}{*}{$\mathrm{KD}$ and $\mathrm{CT}$ (i) UOI } & 0.31 & 0.61 & 0.72 & 0.51 & 0.58 \\
\hline & $(0.29-0.32)$ & $(0.61-0.71)^{\star}$ & $(0.56-0.91)^{\star} \#$ & $(0.51-0.55)^{\star}$ & $(0.57-0.59)^{\star} \#$ \\
\hline \multirow{2}{*}{ SB (i), UOI } & 0.01 & 0.08 & 0.07 & 0.14 & 0.11 \\
\hline & $(0.01-0.02)$ & $(0.08-0.11)^{*}$ & $(0.07-0.09)^{*}$ & $(0.12-0.14)^{\star}$ & $(0.11-0.14)^{\star}$ \\
\hline \multirow{2}{*}{ S POM spont., a.u./mg } & 141.86 & 324.21 & 194.91 & 392.31 & 343.48 \\
\hline & (136.04-166.74) & $(313.48-340.93)^{\star}$ & $(182.07-201.07)^{\star} \#$ & $(272.17-497.71)^{\star}$ & $(332.13-358.22)^{\star} \#$ \\
\hline \multirow{2}{*}{$\begin{array}{c}\text { Aldehyde DNPH } \\
\text { derivatives, \% }\end{array}$} & 93.71 & 92.59 & 91.79 & 89.13 & 90.71 \\
\hline & $(93.69-93.71)$ & (91.61-93.41) & $(91.48-91.98)^{\star}$ & $(88.99-90.02)^{\star}$ & $(90.69-90.71)^{\star}$ \\
\hline \multirow{2}{*}{$\begin{array}{l}\text { Ketone DNPH } \\
\text { derivatives, \% }\end{array}$} & 6.29 & 7.41 & 8.51 & 11.02 & 10.58 \\
\hline & $(6.09-6.31)$ & (6.59-8.38) & $(8.21-9.44)^{*} \#$ & $(10.93-11.12)^{\star}$ & $(10.31-11.34)^{\star}$ \\
\hline \multirow{2}{*}{ uv spont., \% } & 96.57 & 95.57 & 95.32 & 92.88 & 94.58 \\
\hline & $(96.41-96.58)$ & $(95.27-96.01)$ & $(95.29-95.74)$ & $(92.72-93.59)^{\star}$ & $(94.23-95.21)^{\star} \#$ \\
\hline \multirow{2}{*}{ vs spont., $\%$} & 3.42 & 4.42 & 4.71 & 7.11 & 5.76 \\
\hline & $(3.41-3.59)$ & (3.99-4.72) & $(4.67-5.85)$ & $(6.41-7.27)^{\star}$ & $(5.41-6.77)^{\star} \#$ \\
\hline \multirow{2}{*}{$\begin{array}{l}\text { S POM stim., } \\
\text { a.u./mg }\end{array}$} & 266.76 & 380.93 & 321.71 & 662.05 & 544.66 \\
\hline & (256.21-280.81) & $(373.56-427.51)^{\star}$ & $(284.89-377.77)^{*} \#$ & $(643.29-690.09)^{\star}$ & $(479.92-600.42)^{\star} \#$ \\
\hline \multirow{2}{*}{$\begin{array}{c}\text { Aldehyde DNPH } \\
\text { derivatives } \\
\text { stim., \% }\end{array}$} & 86.94 & 89.34 & 83.13 & 81.15 & 83.07 \\
\hline & $(85.98-88.02)$ & (89.03-90.07) & $(82.89-85.89)^{\star} \#$ & $(81.01-83.48)^{\star}$ & $(82.62-87.41)^{\star}$ \\
\hline \multirow{2}{*}{$\begin{array}{l}\text { Ketone DNPH } \\
\text { derivatives } \\
\text { stim., } \% \\
\end{array}$} & 13.05 & 10.65 & 16.86 & 18.84 & 16.92 \\
\hline & $(11.97-14.01)$ & $(9.92-10.96)$ & $(14.11-17.11)^{\star} \#$ & $(16.51-18.99)^{\star}$ & $(12.58-17.37)^{\star}$ \\
\hline \multirow{2}{*}{$\begin{array}{l}\text { uv, } \\
\text { stim., \% }\end{array}$} & 88.99 & 91.91 & 85.67 & 84.52 & 86.13 \\
\hline & $(88.99-90.83)$ & $(91.27-92.31)$ & $(85.44-85.44)^{\star} \#$ & $(83.91-86.37)^{\star}$ & $(85.01-89.91)$ \\
\hline \multirow{2}{*}{$\begin{array}{c}\text { vs } \\
\text { stim., } \%\end{array}$} & 11.01 & 8.09 & 14.32 & 15.47 & 13.89 \\
\hline & $(9.16-11.01)$ & (7.69-8.72) & $(12.19-14.55)^{\star} \#$ & $(13.62-16.08)^{\star}$ & (10.09-14.98) \\
\hline \multirow{2}{*}{ ARP, $\%$} & 54.71 & 80.25 & 49.51 & 57.15 & 42.31 \\
\hline & (51.53-56.71) & $(74.89-87.87)^{\star}$ & $(46.77-51.14)^{\star} \#$ & $(50.11-59.71)$ & $(28.17-47.78)^{\star} \#$ \\
\hline
\end{tabular}

Note: * - difference is significant $(p<0.01)$ relative to group 1 , \# - relative to group 2 . The listed parameters reflect the content of $L P O$ products in the heptane $(g)$ and isopropanol (i) phases of the lipid extract from the mucosal homogenate of the large intestine 
of these conditions. On average, the rats did not lose more than $10 \%$ of their body weight. Such weight loss is traditionally associated with diarrhea and systemic inflammatory response and more specifically with the anorexigenic effect of some proinflammatory cytokines [22]. It is thought that TNBS acts as a hapten and, if administered rectally, induces a Th1 immune response, which involves proinflammatory cytokines and some mediators, against hapten-modified autologous proteins/ luminal antigens or against intestinal microbiota proteins, causing transmural infiltration by leukocytes and inflammation [23-25]. Oxazolone is also seen as a hapten that mediates a Th2 immune response typical to UC, and the majority of researchers prefer it as the most popular agent for modeling UC in rats [26]. The 50\% ethyl alcohol solution used as a solvent for TNBS and oxazolone aggravates damage to the mucosa of the large bowel [27].

Experimental $C D$ and $U C$ are characterized not only by weight loss, frequent defecation and changes to stool consistency but also by the presence of blood in feces and the accumulation of LPO products in the large bowel mucosa. In our experiment, accumulation of LPO products was observed in the isopropanol phase, which primarily accumulates phospholipids of cell membranes, and in the heptane phase (in triglycerides). Besides, there was accumulation of POM products, mainly secondary basic ketone DNPH derivatives, following spontaneous and stimulated oxidation. This led us to hypothesize that combined effects of $\mathrm{OH}^{\cdot}$ and $\mathrm{O}_{2}{ }^{\cdot}$ cause accumulation of late markers of oxidative protein destruction and protein fragmentation [20, 28, 29]. Protein fragments are highly resistant to proteolysis, very toxic and can trigger apoptosis or necrosis, expanding the area of secondary alterations [30]. We have identified a few specific aspects of FRO occurring in the large bowel affected by CD and UC that are related to oxidative destruction of lipids and proteins. Firstly, comparative analysis reveals that the amount of end LPO products in the heptane phase and secondary products in the isopropanol phase measured on day 3 of the experiment, as well as the amount of end and secondary LPO products in the heptane phase and secondary LPO products in the isopropanol phase measured on day 7 , was significantly higher in rats with UC (Table 3). Secondly, comparison of POM products in the homogenized mucosa of the large bowel demonstrates that the adaptive reserve potential and the total content of POM products were higher in the spontaneous and stimulated oxidation modes on days 3 and 7. Besides, in the CD group, as opposed to the UC group, basic primary POM products yielded by spontaneous and stimulated oxidation prevailed on day 3 of observation; on day 7 , basic POM products prevailed in the spontaneous oxidation mode.

We think that escalation of oxidative stress resulting from production of ROS by activated neutrophils, monocytes/ macrophages and endothelial cells in the primary lesion in a situation when the enzymes responsible for antioxidant defense are insufficiently active/scarce increases damage, dysfunction and death of large bowel cells, expands the area of secondary alteration and causes exacerbation of symptoms in patients with CD and UC. This conclusion is supported by the discovered correlations between DAl scores and the amount of $\mathrm{LPO} / \mathrm{POM}$ products in the homogenized large bowel mucosa of rats with induced $U C$ and $C D$.

\section{CONCLUSIONS}

We found that on days 3 and 7 of TNBS-induced CD and oxazolone-induced UC, DAI scores, the amount of primary, secondary and end LPO products in the heptane and isopropanol phases of homogenized intestinal mucosa and the total amount of POM products were increased. In UC, the proportion of secondary basic POM products increased on day 7 . In the setting of UC, FRO was characterized by the accumulation of mostly LPO products, in contrast to CD characterized by the accumulation of mostly POM products. In UC, end LPO products were accumulated in the heptane phase of the lipid extract, whereas secondary products, in the isopropanol phase. CD was characterized by the accumulation of mostly secondary basic POM products. In CD and UC, there was a correlation between DAI scores and the amount of LPO products in the isopropanol phase, as well as the amount of POM products generated by spontaneous oxidation. The highest number of strong correlations was observed for UC. These findings broaden our knowledge about the role of redox state changes in the pathogenesis of inflammatory bowel diseases and encourage further research into FRO affecting the large bowel of patients with CD and UC. LPO and POM products should be investigated in the clinical setting as potential diagnostic markers of the disease and indicators of the efficacy of treatment aimed at reversing exacerbations and prolonging remission.

Table 4. Correlations between DAl scores (c.u.) and FRO in rats with experimentally induced $U C$ and $C D$

\begin{tabular}{|c|c|c|c|c|}
\hline \multirow{3}{*}{ Parameter } & \multicolumn{2}{|c|}{ Day 3} & \multicolumn{2}{|c|}{ Day 7} \\
\hline & Group 2 & Group 3 & Group 2 & Group 3 \\
\hline & $\mathrm{CD}(n=7)$ & $\mathrm{UC}(n=7)$ & $\mathrm{CD}(n=7)$ & $\mathrm{UC}(n=7)$ \\
\hline DC (h), UOI & $R=0.15$ & $R=0.58$ & $R=0.43$ & $R=0.72$ \\
\hline KD and CT (h), UOI & $R=0.51$ & $R=0.82$ & $R=0.32$ & $R=0.66$ \\
\hline SB (h), UOI. & $R=0.13$ & $R=0.17$ & $R=0.43$ & $R=0.88$ \\
\hline DC (i), UOI & $R=0.27$ & $R=0.75$ & $R=0.51$ & $R=0.92$ \\
\hline KD and CT (i), UOI & $R=0.64$ & $R=0.76$ & $R=0.51$ & $R=0.88$ \\
\hline SB (I), UOI & $R=0.32$ & $R=0.31$ & $R=0.67$ & $R=0.72$ \\
\hline S POM spont., a.u./mg & $R=0.69$ & $R=0.77$ & $R=0.83$ & $R=0.89$ \\
\hline S POM stim., a.u./mg & $R=0.41$ & $R=0.85$ & $R=0.63$ & $R=0.81$ \\
\hline
\end{tabular}

Note: significant correlations $(p<0.05)$ are shown in bold. 
1. Corridoni D, Arseneau KO, Cominelli F. Inflammatory bowel disease. Immunology Letters. 2014; 161 (2): 231-35.

2. Dolgushina Al, Husainova GM, Vasilenko GM, Kononenko AG. Rasprostranennost' vospalitel'nyh zabolevanij kishechnika $v$ Chelyabinskoj oblasti. Al'manah klinicheskoj mediciny. 2019; 47 (6): 511-17. Russian.

3. Burisch J, Munkholm P. The epidemiology of inflammatory bowel disease. Scand J Gastroenterol. 2015; 50 (8): 942-51.

4. Su HJ, Chiu YT, Chiu CT, Lin YC, Wang CY, Hsieh JY, et al. Inflammatory bowel disease and its treatment in 2018: Global and Taiwanese status updates. J Formos Med Assoc. 2019; 118 (7): 1083-92.

5. Gajendran M, Loganathan P, Catinella AP, Hashash JG A comprehensive review and update on Crohn's disease. Dis Mon. 2018 Feb; 64 (2): 20-57.

6. Ray G, Longworth MS. Epigenetics, DNA Organization, and Inflammatory Bowel Disease. Inflamm Bowel Dis. 2019; 25 (2): 235-47.

7. Lee SH, Kwon JE, Cho ML. Immunological pathogenesis of inflammatory bowel disease. Intest Res. 2018; 16 (1): 26-42.

8. Tian T, Wang Z, Zhang J. Pathomechanisms of Oxidative Stress in Inflammatory Bowel Disease and Potential Antioxidant Therapies. Oxid Med Cell Longev. 2017; 2017: 4535194.

9. Zhen Y, Zhang H. NLRP3 Inflammasome and Inflammatory Bowel Disease. Front Immunol. 2019; 10 (276). URL: https://www. frontiersin.org/articles/10.3389/fimmu.2019.00276/full (дата обращения: 24.04.2020).

10. Kiernan MG, Coffey JC, Sahebally SM, Tibbitts P, Lyons EM, O'Leary E, et al. Systemic molecular mediators of inflammation differentiate between Crohn's disease and ulcerative colitis, implicating threshold levels of IL10 and relative ratios of proinflammatory cytokines in therapy. J Crohns Colitis. 2020; 14 (1): 118-119.

11. Assadsangabi A, Evans CA, Corfe BM, Lobo A. Application of Proteomics to Inflammatory Bowel Disease Research: Current Status and Future Perspectives. Gastroenterol Res Pract. 2019; 2019: 1426954.

12. Titz B, Gadaleta RM, Lo Sasso G, Elamin A, Ekroos K, Ivanov NV, et al. Proteomics and Lipidomics in Inflammatory Bowel Disease Research: From Mechanistic Insights to Biomarker Identification. Int J Mol Sci. 2018; 19 (9): 2775-96.

13. Ashton JJ, Mossotto E, Ennis S. Personalising medicine in inflammatory bowel disease-current and future perspectives. Transl Pediatr. 2019; 8 (1): 56-69.

14. Morris GP, Beck PL, Herridge MS, et. al. Hapten-induced model of chronic inflammation and ulceration in the rat colon. Gastroenterology. 1989; 3: 795-803.

15. Heller F, Fuss IJ, Nieuwenhuis EE, Blumberg RS, Strober W. Oxazolone Colitis, a Th2 Colitis Model Resembling Ulcerative Colitis Is Mediated by IL13-Producing NK-T Cells. Immunity. 2002; 17 (5): 629-38.

16. Cooper HS, Murthy SN, Shah RS, et. al. Clinicopathologic study

\section{Литература}

1. Corridoni D, Arseneau KO, Cominelli F. Inflammatory bowel disease. Immunology Letters. 2014; 161 (2): 231-35.

2. Долгушина А. И., Хусаинова Г. М., Василенко Г. М., Кононенко А. Г. Распространенность воспалительных заболеваний кишечника в Челябинской области. Альманах клинической медицины. 2019; 47 (6): 511-17.

3. Burisch J, Munkholm P. The epidemiology of inflammatory bowel disease. Scand J Gastroenterol. 2015; 50 (8): 942-51.

4. Su HJ, Chiu YT, Chiu CT, Lin YC, Wang CY, Hsieh JY, et al. Inflammatory bowel disease and its treatment in 2018: Global and Taiwanese status updates. J Formos Med Assoc. 2019; 118 (7): 1083-92.

5. Gajendran M, Loganathan P, Catinella AP, Hashash JG A comprehensive review and update on Crohn's disease. Dis Mon. 2018 Feb; 64 (2): 20-57. of dextran sulfate sodium ex- perimental murine colitis. Lab Invest. 1993; 69 (2): 238-49.

17. Kim JJ, Shajib MS, Manocha MM, Khan WI. Investigating intestinal inflammation in DSS-induced model of IBD. Journal of visualised experiments. 2012; 60 (60): 3678.

18. Volchegorskij IA, Dolgushin II, Kolesnikov OL, Cejlikman VJe. Jeksperimental'noe modelirovanie i laboratornaja ocenka adaptivnyh reakcij organizma. Cheljabinsk: ChelGPU, 2000; 167 s. Russian.

19. Lvovskaya, EI, Volchegorskij IA, Shemyakov SE, Lifshic RI. Spektrofotometricheskoe opredelenie konechnyh produktov POL. Voprosy med. himii. 1991; 4: 92-93. Russian.

20. Dubinina EE. Produkty metabolizma kisloroda $\vee$ funkcional'noj aktivnosti kletok (zhizn' i smert', sozidanie i razrushenie). Fiziologicheskie i kliniko-biohimicheskie aspekty. SPb.: Medicinskaya pressa, 2006; 400 s. Russian.

21. Fomina MA. Sposob kompleksnoj ocenki soderzhaniya produktov okislitel'noj modifikacii belkov $v$ tkanyah i biologicheskih zhidkostyah: metodicheskie rekomendacii. Ryazan', 2014; 60 s. Russian.

22. Antoniou E, Margonis GA, Angelou A, Pikouli A, Argiri P, Karavokyros I, et al. The TNBS-induced colitis animal model: An overview. Ann Med Surg (Lond). 2016; 11: 9-15.

23. Wirtz $S$, Neufert $C$, Weigmann B, Neurath MF. Chemically induced mouse models of intestinal inflammation. Nat Protoc. 2007; 2 (3): $541-6$.

24. Bramhall M, Flórez-Vargas O, Stevens R, Brass A, Cruickshank S. Quality of methods reporting in animal models of colitis. Inflamm Bowel Dis. 2015; 21 (6): 1248-59.

25. Randhawa PK, Singh K, Singh N, Jaggi AS. A review on chemicalinduced inflammatory bowel disease models in rodents. Korean $\mathrm{J}$ Physiol Pharmacol. 2014; 18 (4): 279-88.

26. Weigmann B, Neurath MF. Oxazolone-induced colitis as a model of Th2 immune responses in the intestinal mucosa. Methods Mol Biol. 2016; 1422: 253-61.

27. Ikeda M, Takeshima F, Isomoto H, Shikuwa S, Mizuta Y, Ozono Y, et al. Simvastatin attenuates trinitrobenzene sulfonic acid-induced colitis, but not oxazalone-induced colitis. Dig Dis Sci. 2008; 53: 1869-75.

28. Gubskij Yul, Belenichev IF, Levinskij EL, Kovalenko SI, Pavlov SV, Gancheva OV, i dr. Toksikologicheskie posledstviya okislitel'noĭ modifikacii belkov pri razlichnyh patologicheskih sostoyaniyah. Sovremennye problemy toksikologii. 2005; 8 (3): 20-27.

29. Dalle-Donne I, Scaloni A, Giustarini D, Cavarra E, Tell G, Lungarella G, et al. Proteins as biomarkers of oxidative stress in diseases: the contribution of redox proteomics. Mass Spectrom Rev. 2005; 24: 55-99.

30. Muravleva LE, Molotov-Luchanskij VB, Klyuev DA, Bakenova RA, Kultanov BZH, Tankibaeva NA, i dr. Okislitel'naya modifikaciya belkov: problemy i perspektivy issledovaniya. Fundamental'nye issledovaniya. 2010; 1: 74-78. Russian.

6. Ray G, Longworth MS. Epigenetics, DNA Organization, and Inflammatory Bowel Disease. Inflamm Bowel Dis. 2019; 25 (2): 235-47.

7. Lee SH, Kwon JE, Cho ML. Immunological pathogenesis of inflammatory bowel disease. Intest Res. 2018; 16 (1): 26-42.

8. Tian T, Wang Z, Zhang J. Pathomechanisms of Oxidative Stress in Inflammatory Bowel Disease and Potential Antioxidant Therapies. Oxid Med Cell Longev. 2017; 2017: 4535194.

9. Zhen Y, Zhang H. NLRP3 Inflammasome and Inflammatory Bowel Disease. Front Immunol. 2019; 10 (276). URL: https://www. frontiersin.org/articles/10.3389/fimmu.2019.00276/full (дата обращения: 24.04.2020).

10. Kiernan MG, Coffey JC, Sahebally SM, Tibbitts P, Lyons EM, O'Leary E, et al. Systemic molecular mediators of inflammation differentiate between Crohn's disease and ulcerative colitis, 
implicating threshold levels of IL10 and relative ratios of proinflammatory cytokines in therapy. J Crohns Colitis. 2020; 14 (1): 118-119.

11. Assadsangabi A, Evans CA, Corfe BM, Lobo A. Application of Proteomics to Inflammatory Bowel Disease Research: Current Status and Future Perspectives. Gastroenterol Res Pract. 2019; 2019: 1426954.

12. Titz B, Gadaleta RM, Lo Sasso G, Elamin A, Ekroos K, Ivanov NV, et al. Proteomics and Lipidomics in Inflammatory Bowel Disease Research: From Mechanistic Insights to Biomarker Identification. Int J Mol Sci. 2018; 19 (9): 2775-96.

13. Ashton JJ, Mossotto E, Ennis S. Personalising medicine in inflammatory bowel disease-current and future perspectives. Transl Pediatr. 2019; 8 (1): 56-69.

14. Morris GP, Beck PL, Herridge MS, et. al. Hapten-induced model of chronic inflammation and ulceration in the rat colon. Gastroenterology. 1989; 3: 795-803.

15. Heller F, Fuss IJ, Nieuwenhuis EE, Blumberg RS, Strober W. Oxazolone Colitis, a Th2 Colitis Model Resembling Ulcerative Colitis Is Mediated by IL13-Producing NK-T Cells. Immunity. 2002; 17 (5): 629-38.

16. Cooper HS, Murthy SN, Shah RS, et. al. Clinicopathologic study of dextran sulfate sodium ex- perimental murine colitis. Lab Invest. 1993; 69 (2): 238-49.

17. Kim JJ, Shajib MS, Manocha MM, Khan WI. Investigating intestinal inflammation in DSS-induced model of IBD. Journal of visualised experiments. 2012; 60 (60): 3678.

18. Волчегорский И. А., Долгушин И. И., Колесников О. Л., Цейликман В. Э. Экспериментальное моделирование и лабораторная оценка адаптивных реакций организма. Челябинск: ЧелГПУ, 2000; 167 с.

19. Львовская, Е. И., Волчегорский И. А., Шемяков С. Е., Лифшиц Р. И. Спектрофотометрическое определение конечных продуктов ПОЛ. Вопросы мед. химии. 1991; 4: 92-93.

20. Дубинина Е. Е. Продукты метаболизма кислорода в функциональной активности клеток (жизнь и смерть, созидание и разрушение). Физиологические и клиникобиохимические аспекты. СПб.: Медицинская пресса, 2006;
$400 \mathrm{c}$.

21. Фомина М. А. Способ комплексной оценки содержания продуктов окислительной модисиикации белков в тканях и биологических жидкостях: методические рекомендации. Рязань, 2014; 60 c.

22. Antoniou E, Margonis GA, Angelou A, Pikouli A, Argiri $P$ Karavokyros I, et al. The TNBS-induced colitis animal model: An overview. Ann Med Surg (Lond). 2016; 11: 9-15.

23. Wirtz S, Neufert C, Weigmann B, Neurath MF. Chemically induced mouse models of intestinal inflammation. Nat Protoc. 2007; 2 (3): $541-6$.

24. Bramhall M, Flórez-Vargas O, Stevens R, Brass A, Cruickshank S Quality of methods reporting in animal models of colitis. Inflamm Bowel Dis. 2015; 21 (6): 1248-59.

25. Randhawa PK, Singh K, Singh N, Jaggi AS. A review on chemicalinduced inflammatory bowel disease models in rodents. Korean $J$ Physiol Pharmacol. 2014; 18 (4): 279-88.

26. Weigmann B, Neurath MF. Oxazolone-induced colitis as a model of Th2 immune responses in the intestinal mucosa. Methods Mol Biol. 2016; 1422: 253-61.

27. Ikeda M, Takeshima F, Isomoto H, Shikuwa S, Mizuta Y, Ozono Y, et al. Simvastatin attenuates trinitrobenzene sulfonic acid-induced colitis, but not oxazalone-induced colitis. Dig Dis Sci. 2008; 53: 1869-75

28. Губский Ю. И., Беленичев И. Ф., Левинский Е. Л., Коваленко С. И., Павлов С. В., Ганчева О. В. и др. Токсикологические последствия окислительной модификации белков при различных патологических состояниях. Современные проблемы токсикологии. 2005; 8 (3): 20-27.

29. Dalle-Donne I, Scaloni A, Giustarini D, Cavarra E, Tell G, Lungarella G, et al. Proteins as biomarkers of oxidative stress in diseases: the contribution of redox proteomics. Mass Spectrom Rev. 2005; 24: 55-99.

30. Муравлева Л. Е., Молотов-Лучанский В. Б., Клюев Д. А., Бакенова Р. А., Култанов Б. Ж., Танкибаева Н. А. и др. Окислительная модификация белков: проблемы и перспективы исследования. Фундаментальные исследования. 2010; 1: 74-78 